\title{
Structure-geomorphological features of the largest lakes of Russian North-West
}

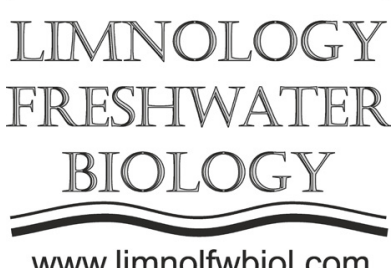

www.limnolfwbiol.com

\author{
Beliaev P. ${ }^{1,2,6}$, Rybalko A. ${ }^{1,6,3}$, Subetto D. ${ }^{5,6}$, Tokarev M. ${ }^{4}$, Aleshin M. ${ }^{4}$ \\ ${ }^{1}$ FSBI “VNIIOkeangeologia", Saint-Petersburg, Russia, Moika promenade 124, 190121 \\ ${ }^{2}$ A. P. Karpinsky Russian Geological Research Institute (VSEGEI), Sredniy ave., 74, Saint-Petersburg, 199106, Russia \\ ${ }^{3}$ Saint-Petersburg state university institute of Earth Science, V.O., 31-33, 10-th line, Saint-Petersburg, 199178, Russia \\ ${ }^{4}$ Lomonosov Moscow State University, , Leninskiye gory, 1, 119234, Moscow, Russia \\ ${ }^{5}$ The Herzen State Pedagogical University of Russia, Moika promenade, 48-50-52, Saint-Petersburg, 191186, Russia \\ ${ }^{6}$ Northern Water Problems Institute, Karelian Research Centre, Russian Academy of Science, NWPI KarRC RAS, Alexandra Nevskogo \\ ave. 50, Petrozavodsk, 185030, Russia
}

\begin{abstract}
Lakes Ladoga and Onega are the largest lakes in the Russian North-West. They are very important from point of view of ecological social-economic aspects of this region for the first time, and they are significant for paleogeography, because lakes is the most representative banks of paleogeografical information about climate changes, especially in quaternary period. But this lakes are weakly studied, the most comprehensive studies at this lakes was at the beginning of 21 century (Makariev et al., 2002; Andreev et al., 2016; Subetto et al., 2009). This work based on results of fieldworks was carried out at the 2014-2019 on the Lakes Ladoga and Onega. During this work, seimoacustic profiling and bottom coring was carried out. The data obtained during field works make it possible to characterize composition of Upper-Pleistocene lacustrine deposits and geomorphological features of these lakes. As the result of data interpretation, geomorphological and geological maps of these lakes was drawn up. It makes possible to correlate structure-geomorphological features of Lakes Ladoga and Onega.
\end{abstract}

Keywords: Geomorphology, Paleolimnology, Qaternary deposits, Pleistocene, Holocene

\section{Introduction}

Lakes Ladoga and Onega - are the lagerst lakes of Russian North-West. In addition, they are most of all significantly from the point of view of paleogeography and ecology for this region. Origin of these lakes was similar with the Great lakes of North America. There are many works, which describe geological and geomorphological features of Ladoga and Onega lakes, however, there are some lag in works which highlight their features in a complex.

\section{Materials and methods}

Data for this article was obtained during fieldworks 2014-2019. During these works were carried out bottom sediment coring and geological sampling, seismoacoustic and side-scan sonar profiling. Geological samples was dated at the laboratory of SaintPetersburg State University. Data, was gained during fieldworks makes possible to characterize geological and geomorphological features of these lakes. In addition to data of field works, for this article we use data of previous researchers (Makariev et al., 2002; Maksimov et al., 2015; Andreev et al., 2016).

\section{Main results}

Bottom sediments of the cores and geophysical materials from Lakes Ladoga and Onega were related with the Upper Pleistocene-Holocene deposits. The following horizons was picked at interpretation of the field data:

1. The $\ln \mathrm{H}$ - Holocene lacustrine deposits, was characterized by brown to gray silt and clayey silts with diagenetic banding of Fe-Mn hydroxides (Strakhovenko et al., 2019).

2. The lgIIIos; lgIIIbl - limnoglacial deposits of Baltic Ice Lake at the Late Valdai. It is presented by composed of gray and brown varved clays with sand lenses and graded layers. These deposits were devided into 3 horizons, which correspond with different stages of a pre-glacial lakes.

3. The fIIIos - fluvioglacial deposits was presented coarse sands with pebbles and clayey sands.

4. The gIIIos - till with bouled loam of the Late Valdai.

In general, geomorphological features of Lake Ladoga evidenced that its northern part was dissected compare to the southern part of the lake bottom. There are three structure-denudative underwater surfaces, widely distribute at the north of the lake; two 
accumulative-denudative surfaces, distribute at the north and in the middle part of the lake bottom; four accumulative surfaces, which widely distribute in the southern part of the lake, but in the north. In addition, there are some sedimentary basins which mount swale features. Lakes Onega and Ladoga have similar geological and geomorphological features.

\section{Conclusions}

Analysis of geological and geophysical data of fieldworks and using data of previous researchers (Makariev et al., 2002; Maksimov et al., 2015; Andreev et al., 2016) allows us to compare structuregeomorphological and geological features of the studied lakes. In geomorphological point of view, the northern parts of both lakes are more dissected, than the southerns. It is clearly that these structures were related with consequence of glacial, neotectonic and fluvial processes in the Late Pleistocene, and structures of pre-quaternary substrate. In the Late PleistoceneHolocene deposits of Lake Onega there are rate more Fe-Mn hydroxides, compare to Lake Onega deposits. In contrast, the Lake Ladoga deposits was enriched by sand, than one of Lake Onega.

\section{Acknowledgments}

This work was supported by grants from St. Petersburg State University № 18.42.1258.2014, №
18.42.1488.2015, №0.42.956.2016, № 18.40.68.2017, № 18-05-00303, the FEEL foundation and projects of the Russian Science Foundation № 18-17-00176, 1417-00766 (RSF).

\section{References}

Andreev A.A., Savelieva L.A., Shumilovskikh L. et al. 2016. German-russian project plot: new palynological data from the lakes Ladoga and Bol'shoe Shuch'e postglacialglacial-preglacial sediment records. Routes of evolutionary geography. [Processing of conference in memory of prof. A.A. Velichko]. Moscow 13-16.

Makariev A.A. 2002. Geological mapping of Onego lake bottom 1:500 000. «PMGRE», Saint-Petersburg.

Maksimov A.V., Bogdanov Yu.B., Voinova O.A. et al. 2015. Gosudarstvennaia geologicheskaia karta Rossiiskoi Federatsii, list P-36 (Petrozavodsk). Masshtab: 1:1000000, Sankt-Peterburg, «VSEGEI», $400 \mathrm{p}+3$ add.

Strakhovenko V., Subetto D., Ovdina E. et al. 2020. Distribution of Elements in Iron-Manganese Formations in Bottom Sediments of Lake Onego (NW Russia) and Small Lakes (Shotozero and Surgubskoe) of Adjacent Territories. Minerals 10. doi: $10.3390 / \min 10050440$

Subetto D.A. 2009. Donnye Otlozheniya Ozer: Paleolimnologicheskie Rekonstruktsii (The Lake-bottom Sediments: A Paleolimnological Reconstruction). Nauchnaya Monografiya (Scientific Monograph). St. Petersburg: Publishing House of Herzen State Pedagogical University of Russia. (in Russian) 